countries. It has been said that all transportation is material waste and if this is so, this source of waste has been very much reduced during the past century, although this may not always be realised as fully as it should. This reduction has been largely due to the improvement of roads, both for horse and power driven vehicles, resulting in greater efficiency, and applies both to roads of earth, stone, etc., and to those using iron and steel rails. It has been also due to the employment of mechanical means of propulsion not only on these roads but also through the air itself.

Sir Henry Fowlen did not deal with propulsion through water, important as it is. He began with a reference to the Leicester and Swannington Railway, which formed so important a step in the commercial development of railways a century ago. This line was essentially due to the courage and forethought of the men of Leicester and its neighbourhood. Up to 1897 , mechanical transport on roads was hindered by Government restrictions, with the result that Great Britain was ten years behind the Continent in start. ing development on these lines. Great Britain was also somewhat behind in transport in the air. In both cases, however, through the knowledge the country had in alloy steels, etc., and in engineering efficiency, it was possible to recover lost ground rapidly. The general scientific knowledge available assisted very materially in the advances in aeronautics. As a result Great Britain has been in the forefront in all types of speed of transportation in recent years. Sir Henry Fowler referred to the recent 15 -ton motor unit for use in the development of fresh country both in the Dominions and Colonies. This has been produced under the supervision of the Overseas Mechanical Transport Directing Committee which was appointed by the Government. The lecture was concluded with a short film showing the performance and possibilities of this vehicle.

\section{Recent Archæological Discoveries in Great Britain}

SEVEral announcements of archæological discoveries of considerable interest have been made within the last few days. Of these, the prehistoric settlement in Papa Westray, Orkney Islands, excites hope of a second Skara Brae. Two large stone buildings, said to be of a type new to Scottish archrology, have been exposed at Hower. The tops of the walls were covered by 6-8 ft. of sand, which had to be cleared away before the buildings were seen. One of the buildings was found to be in an excellent state of preservation, the walls standing to the height of $6 \mathrm{ft}$. The second, however, had suffered considerable damage. The two structures are connected by a passage and open on to a street, which, unfortunately, has disappeared before the encroachment of the sea. It has been possible to plan the structures; but no evidence of the period of occupation has as yet been obtained. The excavations are being carried out by Mr. William Traill of Papa Westray and Mr. W. Kirkness of Edinburgh. A second discovery comes from the Isle of Man, where a gardener at Douglas unearthed a bronze age urn beneath a flat slate slab. There was no indication of the existence of a cist or mound. The urn is $17 \mathrm{in.}$ high and $12 \mathrm{in}$. wide at the mouth, and undecorated, except for irregularly placed dots on the lip. An unusual feature is that the urn stood on its rounded. bottom, under which was a white pebble propping it up. Further search revealed the broken remains of another urn about $5 \mathrm{ft}$. to the south. Underneath this was a platform of black earth with carbon, in some places showing much burning. It is possible, therefore, that this second find represents the vestiges of the incineration, of which the food vessel previously found formed a part. The find is described in the Times of September 5.

IN the same issue of the Times will be found a report on recent excavations in Salmonsbury Camp at Bourton-on-the-Stour, Gloucestershire. Previous discoveries of Iron, Roman and Saxon Age have pointed to this district as being of considerable archæological interest. Salmonsbury Camp itself is an Iron Age structure of some fifty-six acres in extent, which is now being excavated by a local committee under the supervision of Mr. G. C. Dunning of the London Museum. An early Iron Age hut-site was first discovered near the centre of the camp and several similar hut-sites have since been found in other parts. These belong to the first century B.c. Twelve inches above the central Iron Age hut was the floor, partially cobbled and paved with flat stones, of a Roman hut, which yielded pottery and a third century coin. Intervening between these two periods of occupation came evidence of Belgic invasion, in the form of a Belgic hut within the ramparts on the north-west side of the camp. This hut proved rich in finds of pottery, two iron brooches, iron knives, pins, objects of bone, a stone spindle whorl, and worked flints. Fragments of iron and bronze slag and clay point to metal and pottery industries. It is thought that the numerous finds belonging to the Belgic period on the site, point to an invasion of those people, and to them, too, is attributed one of the less pleasing characteristics of the occupants of the site, namely the practice of cannibalism, indicated by the presence of the scattered bones of a female skeleton, some of which appear to have been split to obtain the marrow.

\section{Electric Discharge Lamps}

At the tenth annual conference at Margate of the Association of Public Lighting Engineers, a paper was read on September 5 by Mr. G. H. Wilson on electric discharge lamps and their applications to public lighting. These lamps, which mark a considerable advance in the efficiency of light production, emit light not because any solid is made 'white hot' (as in the case of the filament of the ordinary electric lamp) but because a gas or vapour is 'excited' electrically. When a suitable gas at low pressure is sealed into a glass tube having an electrode at either end, it conducts electricity and light is emitted, the colour of which depends upon the gas used. Mercury vapour produces a blue light, helium an ivory white,

(Continued on p. 405.) 